Carta ao Leitor

Profa. Esp. Sarah Abrahão Gomes dos Santos

Professora de Educação Física

CREF 005039-G/PE

\title{
O esporte coletivo e a regulamentação da profissão
}

Quando as práticas esportivas começaram a ser organizadas, aqueles praticantes com mais habilidades técnicas ou com mais capacidades físicas, assim como aqueles com mais tempo de prática, assumiam a orientação do grupo esportista. Essa fase construiu um terreno fértil e importante nas futuras discussões acerca do esporte e de outras práticas físicas, apontado possíveis necessidades acerca da "cientificação" do treinamento esportivo.

É aquela estória: "A necessidade aguça o engenho". A necessidade de melhorar o desempenho, aumentar índices e reduzir tempos, despertou a curiosidade científica acerca do treinamento esportivo. Surgiram as primeiras relações entre o esporte - até então concebido como algo puramente "prático" - e a ciência. A simples iniciativa de usar papel e lápis para ilustrar situações de jogo e elaborar postura tática, possivelmente estimulou os primeiros estudos associando a execução do gesto motor à um entendimento cognitivo prévio daquela ação no jogo. É possível também, que os primeiros registros dos tempos e marcas apresentadas pelos atletas durante os treinos, tenham despertado a ideia da influência de fatores como alimentação e qualidade do sono no desempenho físico.

A busca por conhecimento e especialização foi veemente nos países cujos atletas estabeleciam novos recordes. O que estimulou países como o Brasil a criar os primeiros cursos de Educação Física. Percebeu-se que antes da ação do gesto motor, existia demanda técnica, tática e das qualidades físicas. O desempenho esportivo passou a ser concebido como algo multifacetado, demandando cada vez mais o uso de papel e lápis, antes, durante e depois de treinos e jogos.

Aqueles praticantes que gostariam de assumir equipes, seguiram os passos dos treinadores que se destacavam, buscando conhecimento técnico-científico para o sucesso na condução dos times. Muitos buscaram as "Faculdades de Educação Física e Desporto", na ânsia de obter conhecimento científico para associar ao acervo prático que carregava da experiência de atleta. Esses cursos de formação superior organizavam-se conforme as demandas da formação de treinadores, explorando conhecimentos que oferecessem suporte na melhora do desempenho esportivo.

Além da fisiologia e biomecânica, outras vertentes científicas da Educação Física começaram a surgir. O esporte, apesar do forte caráter competitivo, passou a ser visto como agente de transformação social e união dos povos. Esporte e educação tiveram seu laço, já existente, ainda mais estreitado. Os currículos de formação superior foram se moldando ao surgimento de novas produções científicas de associação do esporte à formação do cidadão. 
Com tanta "maestria" atribuída ao esporte, - isso porque não falamos das evidências científicas que associaram o esporte enquanto ferramenta para a saúde e qualidade de vida - cresceu a exigência para quem o utiliza enquanto ferramenta de trabalho.

No contexto dessas exigências científicas referentes ao labor com o esporte, podemos discutir sobre as regras estabelecidas a partir da regulamentação da profissão de Educação Física. Tal regulamentação oficializou-se em 01 de setembro de 1998, quando sancionada a Lei no 9696, que cria o Conselho Federal e os Conselhos Regionais de Educação Física. O que muda nesse cenário? Se eu quiser iniciar uma carreira de trabalho com o esporte, a busca por profissionalização técnico-científica passa a ser compulsória, quando antes seria uma opção guiada pela demanda percebida na prática.

O esporte "enche-se de vaidade" e entende-se que o trabalho com condicionamento físico, além de depender de fatores variados é também modificador de realidades e condições. Surgem estudos comprovando o poder de transformação psicossocial do esporte, além das novas publicações científicas que reforçam a capacidade de promoção da saúde com a prática esportiva.

Sobre esses últimos, sempre se caminhou ao consenso. Já sobre a regulamentação da profissão, muitos assumiram posição "contrária". Ora, se entendo que o esporte é ferramenta social e de saúde tão importante, por que me opor ao estabelecimento de regras e condutas para aqueles que farão uso desse instrumento de trabalho? A ideia, depois de "tanta conversa" sobre o esporte, não é a defesa do sistema CONFEF/CREF. Mas existe a necessidade, assim como existiu a demanda de usar papel e lápis para discutir postura tática de jogo, de falar sobre uma profissão, que assim estabelecida, é norteada por regras.

Então, toda essa trajetória do esporte, aqui ilustrada modesta e despretensiosamente, tem como desfecho a criação de uma lei que obriga todos a pagar pelo direito de explorar e aplicar todo o potencial dessa incrível ferramenta? Não! A regulamentação da profissão é só mais um dos largos passos que caminha o esporte, e que o aproxima da feliz realidade de não ser mais abstruso, e sim, congruente e estruturado.

Frequentemente, levanta-se a discussão acerca da real necessidade de atender às regras de regulamentação da Educação Física na oferta de atividade esportiva sem fim lucrativo. Ora, por ser gratuito, filantrópico, humanitário, beneficente - como queira chamar pode ser oferecido de qualquer forma? Já que não posso pagar para praticar esporte num clube onde haja profissionais engajados na organização e aplicação do serviço, já que o poder público não me oferece esse mesmo serviço gratuitamente, eu devo me contentar com aquele que é ofertado sem qualquer organização ou respeito à ciência? Sem papel e lápis? Sem ciência?

É louvável a iniciativa solidária de levar o esporte às comunidades nos diversos ciclos de vida. É indiscutível o rico acervo de conhecimento que a vivência de atleta oferece ao sujeito. Mas se pode melhorar, porque se opor?

Por salutares discussões nesse sentido, precisa-se estimular cada vez mais o uso de papel e lápis (sem ignorar que chegamos à era do computador, internet, softwares e afins, mas 
"papel e lápis" ilustra melhor a ideia de ciência - assim espera-se), nas experiências com o esporte, enquanto agente de transformação social e da condição individual do sujeito. Que periódicos como esse tenham muitas laudas de produção científica reforçando o que já é sabido acerca da intervenção com esporte, regular, periódica e repetida, como método não invasivo que traz reflexos diretos nas questões orgânicas e psíquicas do indivíduo.

Que possamos valorizar o trabalho exaustivo de todos esses estudiosos, cuja produção científica norteia o trabalho do Profissional de Educação física, o trabalho com o esporte. Da mesma forma que um procedimento médico pode trazer benefícios diversos à pessoa, a prática esportiva bem direcionada e orientada também o pode. E o direcionamento correto, o controle de variáveis, dentre outros cuidados, só vai ter, aquele que se debruçou nos tantos papéis produzidos dentro da quadra, do clube, ou de qualquer outro lugar que se faça esporte. Esporte é ciência! Educação Física é ciência! É ciência da saúde! É profissão!

Email: sarahgomes9@gmail.com 